\title{
Basophilic Erythroblast Count
}

National Cancer Institute

\section{Source}

National Cancer Institute. Basophilic Erythroblast Count. NCI Thesaurus. Code C147311.

The determination of the amount of basophilic erythroblasts present in a sample from an experimental org anism. 